REVIEW

\title{
Exhaled breath measures of inflammation: are they useful in neonatal chronic lung disease?
}

\author{
C M Harrison, C C Andersen
}

Arch Dis Child Fetal Neonatal Ed 2005;90:F6-F10. doi: 10.1136/adc.2003.040709

Neonatal chronic lung disease is a common problem for surviving infants of extreme prematurity. Although the precise pathophysiology is still not known, it is clear that inflammation provides a common link that amplifies the injury to the premature lung. Current invasive measures of pulmonary inflammation include markers in blood and airway effluent, with the cellular composition of tracheal fluid being the "gold standard". In this article available exhaled breath measures, particularly nitric oxide, carbon monoxide, volatile hydrocarbons, and exhaled breath condensate, are reviewed with particular reference to sample collection, analysis, and common piffalls as they apply to the ventilated premature newborn at risk of chronic lung disease. Although they have great potential, all measures require thorough validation before being used clinically.

See end of article for authors' affiliations $\ldots \ldots \ldots \ldots \ldots \ldots \ldots \ldots$

Correspondence to: Dr Andersen, Department of Paediatrics, Mercy Hospital for Women, Clarendon St, East Melbourne, Victoria 3002, Australia; candersen@ mercy.com.au

Accepted 11 August 2004
$\mathrm{N}$ eonatal chronic lung disease (CLD) is a common pulmonary outcome for extreme preterm infants. ${ }^{1}$ It is probably the result of a number of interacting factors. ${ }^{23}$ Although the precise pathophysiology is not known, it is clear that inflammation provides a common link that amplifies the injury to the lung. There are a number of broad strategies to ameliorate and/or prevent neonatal CLD. ${ }^{4-7}$ Some have serious side effects $^{8}$ and are prescribed after an individualised cost-benefit analysis.

The cellular composition of tracheal effluent remains the optimal measure of pulmonary inflammation. Exhaled breath has been used to measure inflammatory markers in adults ${ }^{10}$ for over 30 years. A validated breath measure may be of benefit to ventilated newborns by providing a surrogate non-invasive outcome measure, allowing titration of anti-inflammatory treatments, and by predicting at risk infants by defining the profile of CLD.

It is the purpose of this review to outline available exhaled breath measures of inflammation, particularly exhaled nitric oxide (eNO), exhaled carbon monoxide (eCO), volatile hydrocarbons, and exhaled breath condensate (EBC), and to summarise current evidence with particular reference to sample collection, analysis, and common pitfalls.

\section{EXHALED NITRIC OXIDE (ENO)}

NO is synthesised from arginine by NO synthetase. It is produced by a number of different cells including vascular endothelium, airway epithelium, and inflammatory cells. ${ }^{10}$ Endothelial derived NO has been extensively studied in the establishment of pulmonary circulation. ${ }^{11}$ Proinflammatory cytokines (tumour necrosis factor $\alpha$, interleukins 1 and 6) increase the expression of inducible NO synthase ${ }^{12}$ and are increased in bronchoalveolar lavage specimens from newborns with CLD. ${ }^{13}$ Bronchoalveolar lavage nitrite and nitrate, byproducts of NO metabolism, remain raised in premature newborns who develop CLD, possibly reflecting inflammatory upregulation. ${ }^{14}$ In adults, eNO has been validated against measures of inflammation in bronchoscopic specimens ${ }^{10} 15$ and has been measured in obstructive sleep apnoea ${ }^{16}$ and acute respiratory distress syndrome, ${ }^{17}$ and in asthma can predict both loss of control and response to corticosteroids. ${ }^{18}$

eNO has recently been measured in ventilated newborns. ${ }^{19}$ In a small group of ventilated infants, lower airway eNO fell after treatment with dexamethasone. ${ }^{20}$ This is consistent with the inflammatory modulation effect of corticosteroids. ${ }^{21}$

\section{Collection}

In adults, eNO is collected by a single-breath technique and reflects both airway and alveolar production. Both single breath against resistance and multiple tidal breath techniques ${ }^{22}$ have been used to prevent contamination from nasal NO. In ventilated newborns, a 4 French catheter positioned adjacent to the end of the endotracheal tube $^{20}$ has been used for collection of lower airway specimens. ${ }^{23}$

\section{Analysis}

An international taskforce has defined standards and procedures for measurement of eNO in adults and children. ${ }^{24}$ eNO measurement by chemiluminescence has been standardised and is reproducible. ${ }^{25}$

\section{Potential pitfalls}

NO is produced by the paranasal sinuses in adults and is increased in nasal samples from ventilated newborns. ${ }^{23}{ }^{26}$ In addition, eNO concentrations increase in normal subjects after inhaled, intravenous, or digested L-arginine. ${ }^{27} 28$ This needs consideration in newborns receiving parenteral nutrition solutions.

Abbreviations: $\mathrm{CLD}$, chronic lung disease; $\mathrm{NNO}$, exhaled nitric oxide; eCO, exhaled carbon monoxide; $\mathrm{EBC}$, exhaled breath condensate 


\section{Summary}

eNO has great potential in ventilated newborns provided that problems with collection are addressed, particularly partitioning of nasal and lower airway sampling. In addition, further validation against gold standard measures of airway inflammation is needed before eNO can be widely used in premature ventilated newborns.

\section{EXHALED CARBON MONOXIDE (ECO)}

$\mathrm{CO}$ is produced endogenously from the degradation of haemcontaining proteins (haemoglobin) and is a recognised exogenous contaminant. Haem oxygenase is the rate limiting enzyme responsible for degradation of haem to biliverdin and $\mathrm{CO}$ in equimolar amounts. It exists in at least two isoforms, and one of these (HO-1), found mostly in the spleen and liver, is inducible. ${ }^{29} \mathrm{CO}$ binds to haemoglobin as carboxyhaemoglobin and is subsequently excreted in exhaled breath. Thus, eCO can be used as a measure of bilirubin production in vivo. ${ }^{30-33}$ After the exclusion of exogenous CO from environmental contamination and passive diffusion across the placenta, eCO has been shown to be a valid measure of haemolysis ${ }^{34}$ and corrected reticulocyte count in Coombs' test positive term neonates. ${ }^{35}$

Increased concentrations of eCO (fractional concentration of $\mathrm{CO}$ in expired gas) have been reported in patients with inflammatory airway disorders, such as asthma, ${ }^{36}$ cystic fibrosis, ${ }^{37}$ and bronchiectasis. ${ }^{38}$ In adults with cystic fibrosis, concentrations are reduced with antibacterial treatment and corticosteroids, suggesting that it may be a useful marker of inflammation and oxidative stress. ${ }^{39}$ Both oxidants and inflammatory cytokines are capable of inducing haem oxygenase, thereby increasing endogenous CO production. ${ }^{40}$ eCO is increased in infants who later develop $\mathrm{CLD}_{,}{ }^{41}$ and plasma CO concentrations are raised in the paediatric sepsis syndrome. ${ }^{42}$

\section{Collection}

The alveolus is the main site of diffusion, as CO production is unaffected by flow rate but increased with breath holding. ${ }^{43} 44$ In adults, end tidal eCO concentrations have been collected after a period of breath holding. This method is non-invasive, reproducible, and well tolerated. ${ }^{45}$ In a method developed for non-ventilated infants (Natus CO-stat End Tidal Breath Analyser (Natus Medical, San Carlos, California, USA), a small sampling tube inserted into the nostril has been used to draw air continuously across a measuring device at a fixed flow rate. ${ }^{31}{ }^{34}$

\section{Analysis}

Previous researchers have developed a validated end tidal measuring device in non-ventilated infants using an electrochemical sensor. ${ }^{32}$ This device measures both endogenous and exogenous eCO.

\section{Potential pitfalls}

Passive diffusion of CO from infants of smoking mothers may exaggerate eCO in the first 24 hours of life. ${ }^{34}$

\section{Summary}

eCO has already been validated in non-ventilated newborns as a measure of haemolytic disease. However, further validation against standard measures of airway inflammation is needed for concise interpretation, particularly in a population in which sepsis, hyperbilirubinaemia, and inflammatory lung disorders often co-exist.

\section{VOLATILE HYDROCARBONS}

Volatile hydrocarbons are byproducts of lipid peroxidation. The concentration in expired gas, measured by the hydrocarbon breath test, ${ }^{46}$ reflects both endogenous production and exogenous contamination.

Ethane and pentane are low molecular mass hydrocarbons. They are generated by the free radical peroxidation of omega 6 (linoleic) and omega 3 (linolenic) polyunsaturated fatty acids. They have been used as non-invasive markers of active inflammation in obstructive sleep apnoea, ${ }^{16}$ acute asthma (pentane),${ }^{47}$ colitis (animal model) ${ }^{48}$ and rheumatoid arthritis $^{49}$ and as outcome measures in adults with adult respiratory distress syndrome ${ }^{50}$ and chronic obstructive pulmonary disease $\mathrm{e}^{51}$ and premature newborns with respiratory distress syndrome. ${ }^{52}$

In an animal model of colitis, increases in exhaled breath pentane were delayed until day 7 at which time histological examination confirmed acute colonic inflammation. ${ }^{48}$ Pentane concentrations fell during the phase of healing and fibrosis when acute inflammatory cells were no longer present. Further, in adults with rheumatoid arthritis, there is a correlation between both joint inflammation and erythrocyte sedimentation rates and exhaled pentane excretion. ${ }^{49}$ Finally, corticosteroids have been shown to reduce exhaled ethane in adults with asthma..$^{53}$

Infants with CLD have increased lipid peroxidation products measurable in both plasma (thiobarbituric acid reacting substances) and tracheal aspirates (malondialdehyde).$^{54}$ This lipid peroxidation is likely to be increased in the presence of acute neutrophilic inflammation. ${ }^{55}$ In preterm ventilated infants with hyaline membrane disease, pentane concentration peaks on days 4 and 5. This peak correlates with death or CLD, although not with inspired oxygen tension. $^{52}$ Work by Nycyk $^{56}$ in ventilated preterm infants showed a correlation between both exhaled pentane concentration and death and pentane concentration on day 1 and CLD. It is possible that this early pentane peak reflects fetal pulmonary sequestration from placental inflammation. $^{5758}$ Clearly, further validation work is needed before conclusions can be drawn.

The profile of lipid peroxidation byproducts, including exhaled pentane and serum and tracheal aspirate measures, is similar to the evolution of inflammatory cells in tracheal aspirate specimens. ${ }^{59}$ It is plausible that lipid peroxidation reflects oxidative stress that is a consequence of acute pulmonary inflammation.

This is supported by work with isolated granulocytes. ${ }^{60}$ When incubated in pure oxygen, isolated granulocytes produce small amounts of pentane. After granulocyte activation (with the addition of phorbol 13-myristate 12acetate), this production increased by $540 \%$. This response was blunted, although not completely, by the addition of superoxide dismutase and catalase, both well established antioxidants.

After removal of environmental contamination, exhaled hydrocarbon concentrations reflect endogenous lipid peroxidation through a blood-breath interface. This peroxidation is likely to be increased in the presence of acute inflammation, when the activated neutrophil is the most likely metabolically active inflammatory cell. ${ }^{54}$ Although volatile hydrocarbons have been measured in the breath of newborns, they have not been validated against standard measures of pulmonary inflammation.

\section{Collection}

In adult studies, a single-breath technique has been used, with collection into an inert gas tight bag. This allows dead space washout during exhalation. ${ }^{61}$ Previous studies in ventilated newborns have used accessory anaesthetic rebreathing circuits in order to ventilate infants with hydrocarbon-free gas. We have developed a method to capture a significant exhaled volume from a ventilated infant 
without ventilator disconnection. Exhaled gas is trapped on a carrier compound that is stable for long periods, allowing specimens to be batched. Further, ambient (exogenous) hydrocarbons can also be collected, allowing measurement of the small endogenous signal.

\section{Analysis}

The endogenous signal is small (probably $1-10 \mathrm{ppb}$ ) and closely approximates the sensitivity of available measuring devices. Mostly, gas chromatography with mass spectroscopy has been used for analysis. Further care needs to be taken to avoid incorrect analysis of overlapping breath components. ${ }^{62}$

\section{Pitfalls}

Consideration needs to be given to the relatively large concentration of hydrocarbons in ambient air. Some studies have used washout periods with hydrocarbon-free gas. ${ }^{63}$

In addition, infused lipid emulsion contains significant quantities of hydrocarbons ${ }^{64}$ which affect interpretation. After cessation of lipid infusion, exhaled concentrations fall quickly so that, in practice, expired breath can be collected within a short period..$^{65} 66$

It has been suggested that exhaled hydrocarbon concentrations may be affected by contamination from bacterial flora in the gastrointestinal tract. However, during the first few days of life, pentane and ethane excretion increase when the gut is not colonised. ${ }^{52}$

\section{Summary}

Volatile hydrocarbons have been studied in inflammatory illnesses in different populations. The endogenous concentration is very small, highlighting the importance of a collection method that excludes exogenous hydrocarbons, both ambient and infused. Although exhaled hydrocarbons are potentially useful, they require further validation in ventilated newborns.

\section{EXHALED BREATH CONDENSATE (EBC)}

Gas collected by active exhalation after prolonged oral breathing can be cooled or frozen for analysis. This method (EBC) enables components of lung lining fluid to be studied. Evidence suggests that the condensate composition reflects biochemical changes in the extracellular fluid. However, the proportional contributions have yet to be determined. ${ }^{1067}$

Several compounds have been measured including 8isoprostane (from arachidonic acid metabolism), ${ }^{68-70}$ nitrite (byproduct of NO metabolism) ${ }^{71}$ and leukotrienes. ${ }^{72}$ Griese et $\mathrm{al}^{73}$ used EBC to collect hydrogen peroxide in children aged 4 weeks to 18 years. They found that gas collection by active exhalation was very difficult in children younger than about 4-6 years.

\section{CONCLUSION}

CLD remains a problem for surviving infants of extreme prematurity. Current standard measures have been used to describe the evolution of inflammation in very low birthweight infants, although few studies report the profile beyond 2 weeks of age. The development of a non-invasive measure would facilitate the longitudinal management of extremely preterm infants both by defining the illness profile and allowing titration of anti-inflammatory treatments. Further, non-invasive measures need to be developed for infants receiving nasal continuous positive airway pressure. Table 1 summarises the aforementioned measures.

For all measures, issues relating to $(a)$ the large bias flow from the infant ventilator, causing signal dilution, $(b)$ the contribution of environmental contamination, (c) airway humidification, and $(d)$ the biochemical qualities (inertness) of the collection circuit need to be addressed.

Collection methods for both eNO and exhaled hydrocarbons have already been developed for ventilated newborns; however, both systems have potential pitfalls. In nonventilated infants, a method for collection and analysis of eCO is currently available but interpretation is problematic.

Table 1 Summary of exhaled breath measures

\begin{tabular}{|c|c|c|c|c|c|}
\hline & Source & Use & Collection & Analysis & Piffalls \\
\hline \multirow[t]{2}{*}{ Exhaled NO } & $\begin{array}{l}\text { Derived from endothelial, } \\
\text { epithelial, and } \\
\text { inflammatory cells }\end{array}$ & $\begin{array}{l}\text { Measure of pulmonary } \\
\text { inflammation in ventilated } \\
\text { premature newborns and in } \\
\text { adults with obstructive sleep } \\
\text { apnoea, ARDS and asthma. }\end{array}$ & $\begin{array}{l}\text { Airway specimen collected } \\
\text { from endotracheal tube in } \\
\text { ventilated newborns }\end{array}$ & Chemiluminescence & $\begin{array}{l}\text { Production by paranasal } \\
\text { sinuses/nasal passages in } \\
\text { both newborns and adults }\end{array}$ \\
\hline & $\begin{array}{l}\mathrm{NO} \text { synthesised from } \\
\text { arginine by NO } \\
\text { synthetase }\end{array}$ & & $\begin{array}{l}\text { Single breath technique } \\
\text { in adults }\end{array}$ & & $\begin{array}{l}\text { Increased after arginine } \\
\text { infusion }\end{array}$ \\
\hline \multirow[t]{2}{*}{ Exhaled CO } & $\begin{array}{l}\text { Endogenous production } \\
\text { after degradation of } \\
\text { haem-containing proteins } \\
\text { by haem oxygenase }\end{array}$ & $\begin{array}{l}\text { Validated measure of } \\
\text { Coombs positive } \\
\text { haemolysis in non-ventilated } \\
\text { newborns }\end{array}$ & $\begin{array}{l}\text { Intranasal sampling in } \\
\text { non-ventilated newborns }\end{array}$ & Electrochemical sensor & $\begin{array}{l}\text { Passive diffusion of } \mathrm{CO} \\
\text { across the placenta in } \\
\text { infants of smoking mothers }\end{array}$ \\
\hline & Exogenous contaminant & $\begin{array}{l}\text { Inflammatory measure in } \\
\text { adults with asthma, cystic } \\
\text { fibrosis, and bronchiectasis } \\
\text { and in children with sepsis }\end{array}$ & $\begin{array}{l}\text { End tidal breath collection } \\
\text { in adults }\end{array}$ & & \\
\hline \multirow[t]{2}{*}{$\begin{array}{l}\text { Exhaled volatile } \\
\text { hydrocarbons } \\
\text { (pentane, ethane) }\end{array}$} & $\begin{array}{l}\text { Derived from free } \\
\text { radical peroxidation of } \\
\text { membrane bound } \\
\text { polyunsaturated fatty } \\
\text { acids }\end{array}$ & $\begin{array}{l}\text { Correlated with death or } \\
\text { later chronic lung disease } \\
\text { in premature ventilated } \\
\text { infants }\end{array}$ & $\begin{array}{l}\text { Expiratory flow diverted } \\
\text { after period of washout } \\
\text { in ventilated newborns }\end{array}$ & $\begin{array}{l}\text { Gas chromatography } \\
\text { with mass spectroscopy }\end{array}$ & $\begin{array}{l}\text { High concentration in } \\
\text { ambient air and infused } \\
\text { lipid emulsion }\end{array}$ \\
\hline & Exogenous contaminant & $\begin{array}{l}\text { Measure of inflammation in } \\
\text { obstructive sleep apnoea, } \\
\text { asthma, and rheumatoid } \\
\text { arthritis in adults and in an } \\
\text { animal model of colitis }\end{array}$ & $\begin{array}{l}\text { Single breath technique } \\
\text { in adults after similar } \\
\text { washout }\end{array}$ & & $\begin{array}{l}\text { Potential contamination } \\
\text { from collection circuit }\end{array}$ \\
\hline $\begin{array}{l}\text { Exhaled breath } \\
\text { condensate }\end{array}$ & $\begin{array}{l}\text { Derived from varied } \\
\text { components of lung } \\
\text { lining fluid }\end{array}$ & $\begin{array}{l}\text { Preliminary data as a } \\
\text { measure of pulmonary } \\
\text { inflammation in adults and } \\
\text { children }\end{array}$ & $\begin{array}{l}\text { Active exhalation with } \\
\text { subsequent specimen } \\
\text { freezing after prolonged } \\
\text { oral breathing }\end{array}$ & $\begin{array}{l}\text { Varies with each } \\
\text { compound measured }\end{array}$ & $\begin{array}{l}\text { Difficult gas collection } \\
\text { especially in young children }\end{array}$ \\
\hline
\end{tabular}


Finally, EBC has great potential, but a collection method has not been developed. Although these measures offer promise particularly for clinical research, none have been used in the clinical care of ventilated newborns. They all require methodologically sound validation studies before clinical application to ventilated newborns.

\section{Authors' affiliations}

C M Harrison, C C Andersen, Department of Paediatrics, Mercy Hospital for Women, Melbourne, Australia

Competing interests: none declared

\section{REFERENCES}

1 Davis PG, Thorpe K, Roberts R, et al. Evaluating "old" definitions for the "new" bronchopulmonary dysplasia. J Pediatr 2002; 140:555-60.

2 Jobe AH. The new BPD: an arrest of lung development. Pediatr Res 1999;46:641-3.

3 Van Marter U, Dammann O, Allred EN, et al. Chorioamnionitis, mechanical ventilation and postnatal sepsis as modulators of chronic lung disease in preterm infants. J Pediatr 2002;140:171-6.

4 Lauterbach R, Szymura-Oleksiak J. Nebulized pentoxifylline in successful treatment of five premature neonates with bronchopulmonary dysplasia. Eur J Pediatr 1999;158:607

5 Davis JM, Parad RB, Michele T, et al. Pulmonary outcome at 1 year corrected age in premature infants treated at birth with recombinant human CuZn superoxide dismutase. Pediatrics 2003;111:469-76.

6 Russell GA, Cooke RW. Randomised controlled trial of allopurinol prophylaxis in very preterm infants. Arch Dis Child Fetal Neonatal Ed 1995;73:F27-31.

7 Halliday HL, Ehrenkranz RA, Doyle LW. Early postnatal ( $<96$ hours) corticosteroids for preventing chronic lung disease in preterm infants (Cochrane Review). Cochrane Library. Issue 3. Oxford: Update Software, 2003.

8 Barrington KJ. Postnatal steroids and neurodevelopmental outcomes: a problem in the making. Pediatrics 2001;107:1425-6

9 Massaro D, Massaro GD. Dexamethasone accelerates postnatal alveolar wall thinning and alters wall composition. Am J Physiol 1986;251:R218-24.

10 Kharitonov SA, Barnes PJ. Exhaled markers of pulmonary disease. Am J Respir Crit Care Med 2001; 163:1693-722.

11 Ziegler JW, Ivy DD, Kinsella JP, et al. The role of nitric oxide, endothelin, and prostaglandins in the transition of the pulmonary circulation. Clin Perinatol 1995;22:387-403.

12 Nathan C. Nitric oxide as a secretory product of mammalian cells. FASEB J 1992;6:3051-64

13 Kotecha S, Wilson L, Wangoo A, et al. Increase in Interluekin-1 and IL-6 in bronchoalveolar lavage fluid obtained from infants with chronic lung disease of prematurity. Pediatr Res 1996;40:250-6.

14 Vyas JR, Currie AE, Shuker DEG, et al. Concentration of nitric oxide products in bronchoalveolar fluid obtained from infants who develop chronic lung disease of prematurity. Arch Dis Child Fetal Edition 1999;81:F217-220.

15 Barnes PJ. Belvisi MG. Nitric oxide and lung disease. Thorax 1993;48: 1034-43.

16 Olapade CO, Christon JA, Zakkar M, et al. Exhaled pentane and nitric oxide levels in patients with obstructive sleep apnea. Chest 1997;111:1500-4.

17 Brett SJ, Evans TW. Measurement of endogenous nitric oxide in the lungs of patients with the acute respiratory distress syndrome. Am J Respir Crit Care Med 1998; 157:993-7.

18 Payne DNR. Nitric oxide in allergic airway inflammation. Curr Opin Allergy Clin Immunol 2003;3:133-7.

19 Aikio O, Pokela ML, Hallman M. Exhaled and nasal nitric oxide in mechanically ventilated preterm and term newborns. Acta Paediatr 2002;91:1078-86.

20 Williams $\mathrm{O}, \mathrm{Bhat} \mathrm{RY}$, Cheeseman $\mathrm{P}$, et al. Exhaled nitric oxide in chronically ventilated preterm infants. Arch Dis Child Fetal Ed 2004;89:F88-9.

21 Yoder MC, Chua R, Tepper R. Effect of dexamethasone on pulmonary inflammation and pulmonary function of ventilator-dependent infants with bronchopulmonary dysplasia. Am Rev Respir Dis 1991;143:1044-8.

22 Condorelli P, Shin HW, George SC. Characterizing airway and alveolar nitric oxide exchange during tidal breathing using a three-compartment model. $J$ Appl Physiol, 2004 Jan 16 (Epub ahead of print).

23 Williams O, Rafferty GF, Hannam S, et al. Nasal and lower airway levels of nitric oxide in prematurely born infants. Early Hum Dev, 2003 May,
72:67-73.

24 American Thoracic Society. Recommendations for standardised procedures for the online and offline measurement of exhaled lower respiratory nitric oxide and nasal nitric oxide in adults and children. Am J Respir Crit Care Med 1999; 160:2104-117

25 Silkoff PE, McClean PA, Slutsky AS, et al. Marked flow-dependence of exhaled nitric oxide using a new technique to exclude nasal nitric oxide. Am J Respir Crit Care Med 1997; 155:260-7.

26 Artlich A, Busch T, Lewandowski K, et al. Exhaled nitric oxide in preterm infants. Respir Physiol 1998;114:195-200.

27 Sapienza MA, Kharitonov SA, Horvath I, et al. Effect of inhaled L-arginine on exhaled nitric oxide in normal and asthmatic subjects. Thorax 1998;53:172-5

28 Kharitonov SA, Lubec G, Lubec B, et al. L-arginine increase exhaled nitric oxide in normal human subjects. Clin Sci 1995;88:135-9.
29 Stevenson DK, Vreman HJ, Wong RJ, et al. Carbon monoxide and bilirubin production in neonates. Semin Perinatol 2001;25:85-93.

30 Stevenson DK, Ostrander CR, Johnson JD. Effect of erythrocyte destruction on the pulmonary excretion rate of carbon monoxide in adult male Wistar rats. J Lab Clin Med 1979;94:649-54.

31 Stevenson DK, Vreman HJ, Oh W, et al. Bilirubin production in healthy term infants measured by carbon monoxide in breath. Clin Chem 1994:40:1934-9.

32 Stevenson DK, Fanaroff AA, Maisels MJ, et al. Prediction of hyperbilirubinemia in near-term infants. Pediatrics 2001;108:31-9.

33 Stevenson DK, Fanaroff AA, Maisels MJ, et al. Prediction of hyperbilirubinemia in near-term and term infants. J Perinatol 2001;21(suppl 1):S63-72.

34 Herschel $M$, Karrison $T$, Wen $M$, et al. Evaluation of the direct antiglobulin (Coombs') test for identifying newborns at risk for hemolysis as determined by end-tidal carbon monoxide concentration (ETCOc); and comparison of the Coombs' test with ETCOc for detecting significant jaundice. J Perinatol 2002;22:341-7.

35 Javier MC, Krauss A, Nesin M. Corrected end-tidal carbon monoxide closely correlates with the corrected reticulocyte count in coombs' test-positive term neonates. Pediatrics 2003;112:1333-7.

36 Zayasu K, Sekizawa K, Okinaga S, et al. Increased carbon monoxide in exhaled air of asthmatic patients. Am J Respir Crit Care Med 1997; 156:1140-3.

37 Paredi $\mathrm{P}$, Shah PL, Montuschi $\mathrm{P}$, et al. Increased carbon monoxide in exhaled air of patients with cystic fibrosis. Thorax 1999:54:917-902.

38 Horvath I, Loukides S, Wodehouse T, et al. Elevated levels of carbon monoxide in bronchiectasis: a new marker of oxidative stress. Thorax 1998;53:867-70

39 Antuni JD, Kharitonov SA, Hughes D, et al. Increase in exhaled carbon monoxide during exacerbations of cystic fibrosis. Thorax 2000;55:138-42.

40 Otterbein LE, Choi AM. Heme oxygenase: colors of defense against cellular stress. Am J Physiol Lung Cell Mol Physiol 2000;279:L1029-37.

41 Fanaroff A. Carbon monoxide predicts BPD. Southeastern Association of Neonatologists Meeting at Marco Island, May, 2003.

42 Shi Y, Pan F, Li H, et al. Plasma carbon monoxide significantly increased in paediatric sepsis syndrome. Arch Dis Child 2003;88:889-90.

43 Kharitinov SA, Paredi P, Barnes PJ. Methodological aspects of exhaled carbon monoxide measurements as a possible non-invasive marker of oxidative stress: influence of exhalation flow, breath holding and ambient air. Eur Respir J 1998;12:128s.

44 Zetterquist W, Marteus $\mathrm{H}$, Johannesson $\mathrm{M}$, et al. Exhaled carbon monoxide is not elevated in patients with asthma or cystic fibrosis. Eur Respir J 2002;20:92-9.

45 Paredi P, Kharitonov SA, Barnes PJ. Analysis of expired air for oxidation products. Am J Respir Crit Care Med 2002;166:S31-7.

46 Kneepkens CM, Lepage G, Roy CC. The potential of the hydrocarbon breath test as a measure of lipid peroxidation. Free Radic Biol Med 1994; 17:127-60.

47 Olapade CO, Christon JA, Zakkar M, et al. Exhaled pentane levels in acute asthma. Chest 1997;111:862-5.

48 Ondrula D, Nelson RL, Andrianopoulos G, et al. Quantitative determination of pentane in exhaled air correlates with colonic inflammation in the rat colitis model. Dis Colon Rectum 1993;36:457-62.

49 Humad S, Zarling E, Clapper M, et al. Breath pentane excretion as a marker of disease activity in rheumatoid arthritis. Free Radic Res Commun 1988;5:101-6.

50 Carpenter CT, Price PV, Christman BW. Exhaled breath condensate isoprostanes are elevated in patients with acute lung injury or ARDS. Chest 1998;114:1653-9.

51 Paredi P, Kharitinov SA, Leak D, et al. Elevated ethane, a marker of lipid peroxidation, is elevated in chronic obstructive pulmonary disease. Am J Respir Crit Care Med 2000;162:369-73.

52 Varsila $\mathrm{E}$, Pitkanen $\mathrm{O}$, Hallman $\mathrm{M}$, et al. Immaturity-dependent free radical activity in premature infants. Pediatr Res 1994;36:55-9.

53 Buss IH, Darlow BA, Winterbourn CC. Elevated protein carbonyls and lipid peroxidation products correlating with myeloperoxidase in tracheal aspirates from premature infants. Pediatr Res 2000;47:640-5.

54 Jones HA, Clark RJ, Rhodes CG, et al. In vivo measurement of neutrophil activity in experimental lung inflammation. Am J Respir Crit Care Med 1994; 149:1635-9

55 Paredi P, Kharitonov SA, Barnes PJ. Elevation of exhaled ethane concentration in asthma. Am J Respir Crit Care Med 2000;162:1450-4.

56 Nycyk JA. Breath Pentane as a marker for lipid peroxidation and adverse outcome on preterm infants. Arch Dis Child Fetal Neonatal Ed 1998;79:F67-9.

57 Merritt TA, Stuard ID, Puccia J. Newborn tracheal aspirate cytology: classification during respiratory distress syndrome and bronchopulmonary dysplasia. J Pediatr 1981;98:949-56.

58 Grigg J, Arnon S, Chase A, et al. Inflammatory cells in the lungs of premature infants on the first day of life: perinatal risk factors and origin of cells. Arch Dis Child 1993:69:40-3.

59 Scott RJ, Peat D, Rhodes CA. Investigation of the fetal pulmonary inflammatory reaction in chorioamnionitis, using an in situ $Y$ chromosome marker. Pediatr Pathol 1994; 14:997-1003.

60 Pitkanen OM, Hallman M, Andersson SM. Determination of ethane and pentane in free oxygen radical induced lipid peroxidation. Lipids 1989;24:157-9.

61 Zarlin EJ, Clapper M. Technique for gas-chromatographic measurement of volatile alkanes from single-breath samples. Clin Chem 1987;33:140-1. 
62 Springfield JR, Levitt MD. Pitfalls in the use of breath pentane measurements to assess lipid peroxidation. J Lipid Res 1994;35:1497-504.

63 Drury JA, Nycyk JA, Cooke RW. Pentane measurement in ventilated infants using a commercially available system. Free Radic Biol Med 1997;22:895-900.

64 Pitkanen OM, Hallman M, Andersson SM. Generation of free radicals in lipid emulsion used in parenteral nutrition. Pediatr Res 1991;29:56-9.

65 Wispe JR, Bell EF, Roberts RJ. Assessment of lipid peroxidation in newborn infants and rabbits by measurements of expired ethane and pentane: influence of parenteral lipid infusion. Pediatr Res 1985;19:374-9.

66 Pitkanen OM, Luukkainen P, Andersson S. Attenuated lipid peroxidation in preterm infants during subsequent doses of intravenous lipids. Biol Neonate. 2004;85: 184-7, Epub 24 Dec, 2003.

67 Freels JL, Robbins RA, Campbell SC. Exhaled breath condensate: the past, present, and future. Clinical Pulmonary Medicine 2003;10:263-8.

68 Carpagnano GE, Kharitonov SA, Resta O, et al. 8-Isoprostane, a marker of oxidative stress, is increased in exhaled breath condensate of patients with obstructive sleep apnea after night and is reduced by continuous positive airway pressure therapy. Chest 2003;124:1386-92.

69 Montuschi P, Corradi M, Ciabattoni G, et al. Increased 8-isoprostane, a marker of oxidative stress, in exhaled condensate of asthma patients. Am J Respir Crit Care Med 1999;160:216-20.

70 Baraldi E, Carraro S, Alinovi R, et al. Cysteinyl leukotrienes and 8-isoprostane in exhaled breath condensate of children with asthma exacerbations. Thorax 2003;58:505-9.

71 Gessner C, Hammerschmidt S, Kuhn H, et al. Exhaled breath condensate nitrite and its relation to tidal volume in acute lung injury. Chest 2003;124:1046-52.

72 Biernacki WA, Kharitonov SA, Barnes PJ. Increased leukotriene B4 and 8isoprostane in exhaled breath condensate of patients with exacerbations of COPD. Thorax 2003:58:294-8.

73 Griese M, Latzin P, Beck J. A noninvasive method to collect nasally exhaled air condensate in humans of all ages. Eur J Clin Invest 2001;31:915-20.

\section{IMAGES IN NEONATAL MEDICINE.}

\section{Alcohol burns in extremely low birthweight infants: still occurring}

D elivery of an extremely premature infant presents a number of challenging issues, and placement of central lines is an important part of the early management of these vulnerable babies. Alcohol based skin cleansers such as chlorhexidine gluconate $0.5 \%$ in $70 \%$ methano are widely used before insertion of umbilical and percutaneous central lines and are effective at achieving skin sterilisation in neonates. ${ }^{1}$ Despite previous reports, ${ }^{2}$ we have recently seen two cases of infants born at 24 weeks gestation who sustained extensive abdominal burns from chlorhexidine/alcohol applied during the insertion of umbilical catheters before transfer to our unit.

Hypothermia, excessive water loss, sepsis, and renal failure are all recognised consequences of severe burns in the neonate. Additionally pain and stress may adversely affect neuronal maturation in the brain, ${ }^{4}$ and skin scarring and depigmentation are common.

In summary, the use of alcohol based skin cleansers in babies with immature skin $(<28$ weeks $)$ is inappropriate, and we remind paediatricians who may be inserting (usually umbilical) lines that skin cleansers should be chosen that are suitable for the skin maturity. We take great care to avoid pooling of cleanser under the infant, and use saline for immature skin.

P R Reynolds, S Banerjee, J H Meek Neonatal Intensive Care Unit, University College London Hospitals, Elizabeth Garrett Anderson and Obstetric Hospital, Huntley Street, London WC1E 6DH peter.reynolds@uclh.org

Competing interests: none declared

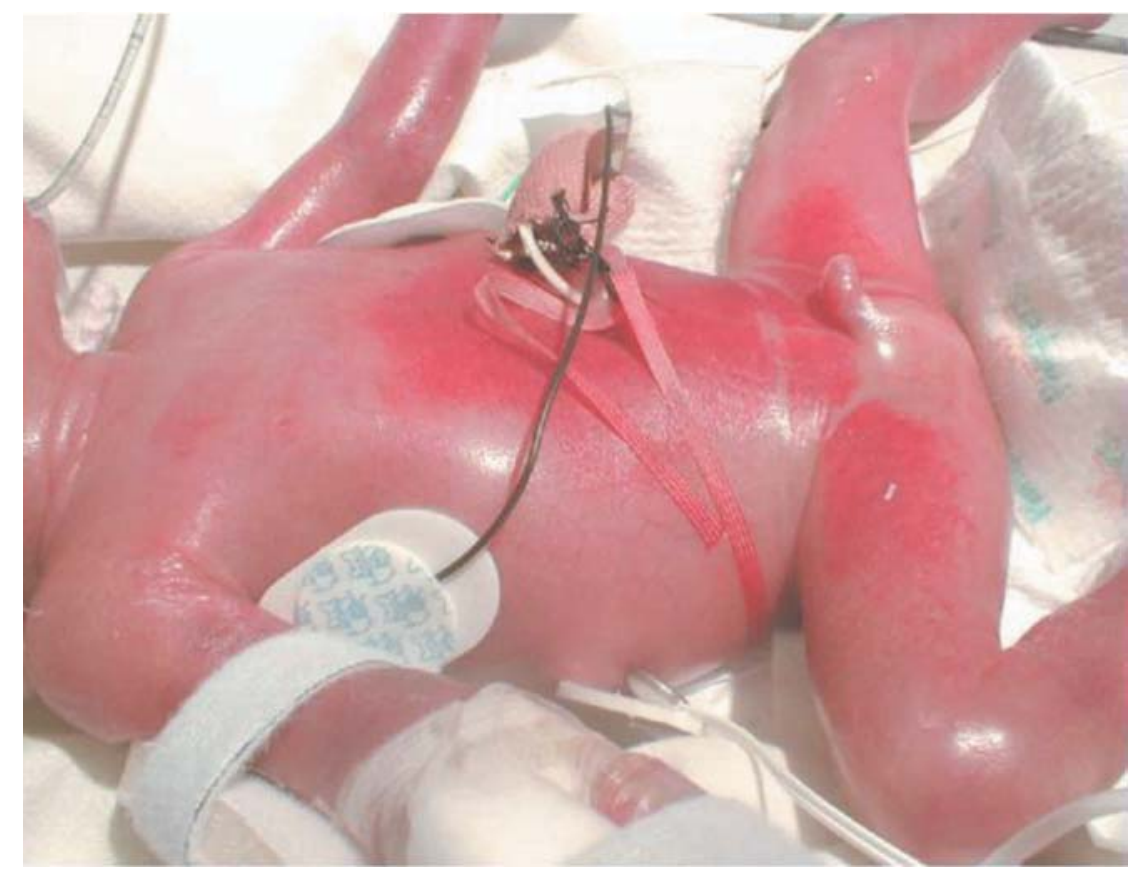

Figure 1 This $644 \mathrm{~g}$ baby sustained extensive burns over the abdomen and upper thighs. He became hypothermic $\left(32.6^{\circ} \mathrm{C}\right)$, hypernatraemic, and subsequently developed systemic fungal sepsis with extensive skin breakdown. After two weeks the skin had healed without apparent cosmetic damage, but he died from renal failure 25 days later. This figure is published with parental consent.

\section{REFERENCES}

1 Garland JS, Buck RK, Maloney P, et al. Comparison of $10 \%$ povidone-iodine and $0.5 \%$ chlorhexidine gluconate for the prevention of peripheral intravenous catheter colonisation in neonates: a prospective trial. Pediatr Infect Dis J 1995;14:510-16.

2 Watkins AM. Alcohol burns in the neonate. J Paediatr Child Health 1992;28:306-8.

3 Schick JB, Milstein JM. Burn hazard of isopropyl alcohol in the neonate. Pediatrics 1981;68:587-8.

4 Bhutta AT, Anand KJ. Vulnerability of the developing brain. Neuronal mechanisms. Clin Perinatol 2002:29:357-72. 